\title{
О НЕКОТОРЫХ АСПЕКТАХ ФЕНОМЕНА «РЕЛИГИОЗНОГО ВОЗРОЖДЕНИЯ» В СОВРЕМЕННОМ УКРАИНСКОМ ОБЩЕСТВЕ
}

\author{
Р.И. Амирова, Л.А. Медведева
}

Сегодня вряд ли можно найти серьезных оппонентов тому очевидному факту, что важнейшим принципом устройства современного социума яв.ляется плюрализм во всех формах социального бытия и общественного сознания как наиболее естественная форма человеческого существования. Именно поэтому, на наш взгляд, нынешний этап общественного развития характеризуется весьма энергичным провозглашением прав человека, стремлением к реализации фундаментальных социальных и духовных ценностей, касающихся прежде всего человеческого достоинства, суверенитета и свободы.

Следует однако заметить, что эти процессы протекают достаточно неоднозначно и болезненно, вызывая целый ряд острейших проблем концептуального и практического характера. Во-первых, формула «люди рождаются свободными и равными», в которой выражены основные права человека, как и всякое другое право, не имеет смысла вне признания её всей общностью людей. А, во-вторых, она же требует необходимости осмысления и разрешения вопроса о границах свободы и необходимости, о пределах морально допустимого и осуществимого, контурах должного и сущего.

Более ста лет назад Евгений Дюринг сконструировал «универсальную», на его взгляд, теорию социально-личностных отношений, в основе которой лежала модель взаимодействия двух совершенно равных социальных субъектов, не имеющих малейшего права что-либо навязывать другому. Эта концепция провозгласила принцип контингентно-

Актуальні проблеми духовності

(Відп. ред.: Я.В. Шрамко)

Кривий Pir (2008), 366-372 
сти в общественных отношениях вне долженствующей свободы, кредо крайнего релятивизма и индивидуализма, для которого невыносима ясность сознания, связанная с действием силы общего в отдельных вешах и неминуемо даёт о себе знать фетиш отдельного. Однако свобода не есть индивидуально-эгоистическое своеволие, ибо предполагает равное право на свободу всех других индивидов, а не только независимое бытие отдельного «вольного» человека. Вне этого свобода превращается в банальный цинизм и уничтожает самое себя ${ }^{1}$. Не этот ли произвол (но не свобода), раскрепостив потенциал личности в координатах индивидуализма новоевропейской традиции, привёл к воЗникновению нынешней духовно-нравственной, а точнее, бездуховной и безнравственной социокультурной ситуации в обществе?

Потеря креативного социального потенциала и сужение духовного горизонта вследствие высвобождения стихии анархии, питающей современный жизненный мир, находящийся в пространстве плюрализма приватных интересов (Ю. Хабермас), существенно обедняет человеческую природу и общественную моральную практику. Следовательно, важна не свобода как таковая, а культура свободы и её духовные горизонты, которые, по И. Канту, определяются жизнетворческими основаниями и смыслами, видятся не столько в освоении всего объёма внешней (объективной) свободы, сколько в создании свободы внутри себя, то есть свободы субъективной.

Вместе с тем, рассматривая свободу как человеческое благо, достойное защиты и развития, необходимо учитывать, что её воплощение возможно только в контексте актуализации тех правовых и моральных устоев обцества, которые наполняют её содержанием и значимостью в результате перевода из сферы абстрактного в сферу социальньх реалий. Особенно это касается такой имманентно интимной и деликатной сферы свободы как свобода совести, ибо дихотомия верыневерия всегда была лезвием бритвы и нередко становилась причиной драматических, а порой и трагических социальных коллизий. Эта сторона свободы приобретает особую актуальность во времена радикальных общественных трансформаций, вызывающих к жизни самые разнообразные умонастроения, религиозные движения и течения, что сегодня мы наблюдаем внутри переходного украинского социума, поликонфессиональная палитра религиозного бытия которого является своеобразной почвой как для мировоззренческих противоречий, так и

\footnotetext{
1 Зандкюлер Х.Й. Демократия, всеобщность права и реальный плюрализм // Вопросы философин. - 1991.- N22.
} 
для конфликтов в социальной практике.

В этой ситуации особого рассмотрения заслуживает так называемый «религиозный ренессанс», с которым некоторые исследователи связывают возрождение религиозной веры и усиление позиций религиозных организаций в обществе. Приводя в подтверждение әтому немало статистических выкладок, они акцентируют внимание на том, что за годы независимости в Украине явно обозначилась тенденция к значительному росту религиозных организаций, особенно в рамках мировых конфессий. Так, в православии, составляющем более половины религиозного пространства украинского общества, их число увеличилось вдвое, в католицизме - в 1,5 раза, протестантизме-почти в 2,5 раза, а в буддизме и исламе возросло впятеро ${ }^{2}$.

Вряд ли нужно сомневаться в том, что приведенные статистические сведения адекватно отражают характер и содержание социальных и духовных процессов, происходящих в украинском обществе. Можно лишь, во-первых, усомниться в том, что внешний количественный прирост есть подлинный «ренессанс» духа и религиозной веры, сакральных ценностей и идеалов и, во-вторых, отметить, насколько подобное собственное нетерпение отдельных исследователей при оценке всего лишь тенденций, хотя и достаточно убедительных, стремление выдать желаемое за действительное мешают, а то и попросту вредят глубокому и всестороннему изучению того или иного явления.

Если исследовать и оценивать феномен украинского религиозного «ренессанса» в комплексе с другими аспектами социального бытия, без отрыва от общих тенденций развития мирового сообщества, то становится очевидным, что он практически не выпадает (за исключением некоторых национальных особенностей) из общего русла глобальных трансформаций современного мира.

Уже в прошлом веке планетарный социум оказался в глубокой техногенной ловушке, где научно-технический прогресс доминирует не только над внешней материальной культурой современной цивилизации, но и над ее фундаментальными духовными основами, определяя характер и содержание ее идеологии, мировоззрения, ценностей и т. д. Утверждение техногенной парадигмы его развития повлекло за собой мощную волну секуляризационных процессов, которые лишили религию цивилизационно-креативного смысла, ограничив ее роль приватной сферой и превратив ее до некоторой степени в периферийное

${ }^{2}$ Расчет сделан на основе матерналов журнала «Релігійна панорама» за 2001 2002 годы. 
фольклорное явление. Подобный разрыв между социальнозначущим и социальносущим, трансформация бытия из высшего дара в средство, в технический мир инструментальной активности человека предельно драматизировали вопрос о его месте в универсуме.

Человек оказался один на один со своей собственной телесностью на фоне невероятного разнообразия повседневности, в результате чего мир чувственности превратился в главную ценность. Вертикаль духовности осела, перекосилась и частично разрушилась, а религия потеряла значение доминирующего идейного и нравственного императива духовной жизни. Не случайно еще в 30-е годы ушедшего столетия Питирим Сорокин, анализируя историческую динамику содержания и характера художественного творчества, пришел к выводу о том, что «когда в некой данной культуре изменяется доминирующая сверхсистема, то в этом же направлении меняются все формы ... искусств» ${ }^{3}$. Из его анализа следует, что по сравнению с XII веком в XX веке доля религиозных картин падает до 3,9 процентов, в то время как в XII веке она составляла 97 процентов. Среди ведущих музыкальных сочинений по сравнению со средними веками «доля религиозных снижается до 42 процентов в XVII-XVIII веках, до 21 процента в XIX веке и до 5 процентов в XX веке. Процент же светских сочинений вырастает до 95 процентов» ${ }^{4}$. Это же наблюдается в словесности, где в XX веке процент светских произведений поднимается в зависимости от регионов до $80-90$ процентов ${ }^{5}$.

Подобное уменьшение количества произведений искусства, основанных на принципах религиозного восприятия мира (по Сорокину на принципах доминирования идеациальной сверхсистемы культуры), и увеличение таких, которые базируются на светских идеалах и ценностях (на принципах чувственной сверхсистемы), свидетельствуют об устойчивом историческом процессе секуляризации мирового социума и в пространстве, и во времени.

Как показывает сравнительный анализ темпов роста верующего и неверующего населения при увеличении населения планеты в прошлом веке в 3,7 раза (в т. ч. в 1,9 раза в странах Европы и СНГ), темпы роста количества последователей мировых религий значительно уступали количественному росту неверующих. Если эволюция религиозного мира практически соответствовала темпам роста народонаселения, то темпы секуляризационных процессов превышали её в десятки раз: ко-

\footnotetext{
${ }^{3}$ Сорожин П. Человек. Цивилизапия. Общество. - М., 1992.- С. 439.

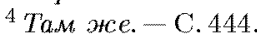

${ }^{5}$ там же.- С. 445 .
} 
личество неверующих во всем мире к концу прошлого века выросло с 5,1 миллиона до 1,2 миллиарда человек, в Европе и странах СНГ - с 2 до 151 миллионов, что превышает темпы прироста приверженцев мировых конфессий более чем в 50 раз ${ }^{6}$. Все это свидетельствует о том, что перед нашими современниками, как, впрочем, и перед предшествующими поколениями, встают далеко не умозрительные, а вполне экзистенциальные вопросы о смысле бытия, о месте религии в его жизни, о способности светских и религиозных начал удовлетворять его потребности.

В этой парадигме вера и разум, религиозность и свободомыслие не могут рассматриваться иначе, как уникальные и равноправные, хотя и принципиально разные сферы общественной жизни и приватного опыта личности. Именно поэтому, говоря о «религиозном буме» не следует забывать и об иной, оппонирующей стороне общественного сознания, а именно свободомыслии во всех его разновидностях: богоборчестве, скептицизме, антиклерикализме, индифферентизме, светском гуманизме, атеизме и т.д., тем более, что в современном украинском обществе свыше 43 процентов населения относят себя к этой системе мировоззренческих (в частности, аксиологических) координат. При этом, если среди женщин удельный вес неверующих, колеблющихся и атеистов составляет 32 процента, то среди мужчин он возрастает до 54 процентов, что свидетельствует об их более высокой восприимчивости к процессам отчуждения от религии.

Разумеется, мы предприняли подобный культурно-статистический экскурс не с целью отрицания оживления религиозной зкизни общества после ниспровержения «воинствующего государственного атеизма». Ведь несмотря на все секуляризационные процессы и их следствия, которые можно отнести к внешним, но, однако, существенным факторам, влияющим на расстановку ценностных акцентов, религия действительно занимает большое место в жизни как мирового социума в целом, так и украинского общества в частности, претерпевая при этом Значительные изменения и трансформации, обусловленные противоречиями современного этапа его развития. Мы лишь хотели подчеркнуть, что одной из модальностей времени становится плюрализм, проникающий во все сферы общественного сознания, в том числе и религиозную.

Вместе с тем, особенность украинского религиозного возрождения

\footnotetext{
${ }^{6}$ Сравнительный анализ сделан на основе публикаций в журнале «Релігійна панорама» за 2002 год.
} 
в континууме духовного поиска и духовной регенерации социума заключается не только в реанимации традиционных культов, но и в стимулировании интереса к совершенно новым религиозным движениям и верованиям, что, на наш взгляд, сродни политическим трансформациям внутри украинского обцества. Реформы конца ХХ века привели к ментальному кризису и определенному вакууму, который, с одной стороны, предоставил возможкность реализации религиозных экспектаций, а с другой - стимулировал стремительный рост политических партий, количество которых за. годы независимости достигло 130 всеукраинских объединений, презентующих самую разнообразную и разноцветную палитру общественно-политической жизни и социальных устремлений их приверженцев.

Следует заметить, что подобный резкий экспонентный количественный рост не всегда сопровождается качественными изменениями в общественном сознании и социальной практике. Как результат, количественный рост религиозных организаций в современном украинском обществе нередко оборачивается процессами религиозной деконструкции, десакрализации и индивидуализации религии, то есть ведет к существенному изменению ее социально-духовного статуса, роли и функций, а также характера и содержания поведения верующих. Именно отсутствие однозначной определенности религиозного познания и религиозного бытия, углубления дифференциации внутри религиозного пространства является сегодня великим искушением как для последовательных адептов той или иной веры, так и для околоцерковных (в т. ч. и внецерковных) кругов, усиливая, с одной стороны, общую мировоззренческую неуверенность, ценностную путаницу и идейную относительность, а с другой-расширяя потенциальную базу духовных конфликтов. Все это является следствием такой системы истины, которая развивает темпоральный, релятивистский и нигилистический склад ума, отрицающего вечные ценности и вытесняющего их временными и быстротекущими соображениями в соответствии с чувственным Carpe diem ${ }^{7}$.

Как свидетельствуют социологические опросы, религиозность и религиозное поведение в современном украинском социуме в большей степени являются атрибутом этикета, нежели следствием духовного труда в виде ценностной мотивационной составляющей религиозных потребностей личности. Они, во-первых, строго не дифференцируются ни в культовой, ни в социальной практике индивидов, а вероятнее

\footnotetext{
${ }^{7}$ Сорожин ПI. Человек. Цивилизация. Общество. - М., 1992. - С. 470.
} 
всего подчинены их корпоративному желанию (но не духовному стремлению) идентифицировать себя с определенной социальной группой, а не с принадлежностью к той или иной вере как духовному чувству. Сегодня отношение к религии, несмотря на внешнюю кажимость ее расцвета, во многом является данью моде, а не следствием глубоких внутренних убеждений, результатом существующих противоречий между системами институционированных ценностей, возникших в условиях трансформации современного социума, определенного разрыва между отнесением себя к религиозной среде и осознанием себя истинно верующим человеком.

И даже принимая во внимание тот факт, что, по мнению мирового сообщества, в Украине создано достаточно демократичное и корректное во многих вопросах законодательство, регулирующее аспекты свободы совести, приходится всё же констатировать живучесть поверхностного и селективного подхода к этой проблеме и в научных кругах, и в среде политического бомонда, пытающегося порой прагматично и эгоистично использовать ее для реализации своих целей, равно как и в церковных кругах в виде разного рода претензий на «исключительность» своей веры. В этой связи нелишним будет напомнить слова известного английского писателя, автора «Хроник Нарнии» K.С. Льюиса о том, что в общественной жизни «ещё не раз доведется увидеть подделки под богословие в интересах левых и в интересах правых. И то, и другое будет мерзостью запустения на месте святе» ${ }^{8}$.

Вывод из этого, как нам представляется, может быть лишь один свобода совести (как, впрочем, и любой другой аспект свободы) останется фикцией, утопией и блажью, если ее декларация (пусть даже самая презентабельная) не совпадёт, как минимум, с тремя факторами. Вопервых, с развитой, духовно богатой и готовой к этому ментальностью нации, скрепляющей единство культурной традиции и выполняющей интегрирующую функцию, синтезируя определённое миропредставление, мироощущение, миропонимание и мироотношение. Во-вторых, с политическим волеизъявлением нации в виде конституционно-правовых норм. И, в-третьих, с последовательной (честной, открытой и прозрачной) реализацией этих норм государством в лице его властных институтов и политической элиты, причём последней в особенной степени, так как именно она в значительной степени может влиять на характер и содержание общественных процессов.

\footnotetext{
${ }^{8}$ Цит. по: Aверинцев С.C. Голос, которому можно верить // Этическая мысль: Научно-публицистические чтения 1991.- М., 1992.-С.442.
} 